\title{
Asynchronous Appearance and Topographic Segregation of Neuropeptide-Containing Cells in the Developing Rat Adrenal Medulla
}

\author{
Paul D. Henion and Story C. Landis \\ Department of Neurosciences, Case Western Reserve University, School of Medicine, Cleveland, Ohio 44106
}

The developmental expression of neuropeptide $Y$ (NPY) and leucine-enkephalin (L-Enk) was examined in embryonic, early postnatal, and adult chromaffin cells with double- and triple-label immunocytochemical techniques and compared to the expression of immunoreactivity for tyrosine hydroxylase (TH) and phenylethanolamine $\mathrm{N}$-methyltransferase (PNMT). In addition, the establishment of preganglionic innervation was assessed by labeling for choline acetyltransferase (ChAT) and L-Enk. NPY-IR was detectable on embryonic (E) day 15 in a clustered subpopulation of TH-IR cells. L-Enk and PNMT-IR cells were initially present on E16 in a separate nonclustered population of TH-IR cells. By late embryonic development, twice as many TH-IR cells expressed NPY and 4 times as many expressed L-Enk as in the adult. In contrast to early embryonic development, NPY-IR was evident in both the clustered and nonclustered subpopulation of TH-IR cells at this time. The proportion of NPY-IR chromaffin cells decreased to adult values during the first postnatal week at the time when obviously clustered TH-IR cells were no longer observed. The embryonic rise in the proportion of L-Enk-IR cells correlates with the developmental increase in glucocorticoid production, while the postnatal decrease corresponds to the appearance of ChAT-IR in the preganglionic innervation of the adrenal medulla. These results indicate that NPY and L-Enk are expressed at different times and in different subpopulations of cells in the embryonic adrenal. Further, the observation that peptide expression by chromaffin cells undergoes marked changes during development raises the possibility that a number of factors including developmental history, environmental signals and impulse activity play a role in the regulation of neuropeptide expression in sympathoadrenal derivatives of the neural crest.

The sympathoadrenal lineage of the neural crest gives rise to sympathetic neurons, adrenal chromaffin cells, and small intensely fluorescent (SIF) cells. Although these cell types differ in morphology and position in the animal, they are similar in that they contain catecholamines and neuropeptides. For ex-

Received Jan. 2, 1990; revised Mar. 28, 1990; accepted Apr. 2, 1990.

This work was supported by HD25681 and training grant NS 07118. We wish to thank Dr. Ann Acheson for useful discussions and the kind gift of the TH monoclonal antibody, Ilene Browner and Dr. Mahendra Rao for assistance in generating the NPY antiserum, and Drs. Miles Epstein and Jean Thibault for the ChAT and TH antisera, respectively.

Correspondence should be addressed to Paul D. Henion at the above address.

Copyright (C) 1990 Society for Neuroscience $0270-6474 / 90 / 092886-11 \$ 03.00 / 0$ ample, most rat sympathetic neurons contain norepinephrine and NPY (Lundberg et al., 1982) or enkephalin (Schultzberg et al., 1979), while chromaffin cells contain norepinephrine or epinephrine and NPY (de Quidt and Emson, 1986; Schalling et al., 1988) or enkephalin (Schultzberg et al., 1978; Bohn et al., 1983).

Attention has focused on the development of catecholaminergic properties and possible mechanisms that regulate their expression in cells of the sympathoadrenal lineage. The acquisition of noradrenergic traits occurs early in the developmental history of sympathetic neurons and adrenomedullary cells. Expression of catecholamine histofluorescence and immunoreactivity for synthetic enzymes is first detectable in sympathetic precursors when neural crest cells begin to aggregate to form sympathetic ganglia (DeChamplain et al., 1970; Cochard et al., 1979; Teitelman et al., 1979; Rothman et al., 1980). In the adrenomedullary system, TH-IR precursor cells undergo a secondary migration from the sympathetic chain into the forming adrenal gland. The precursor cells continue to express TH-IR during migration and subsequently in the adrenal gland (Verhofstad et al., 1979; Bohn et al., 1981; Henion and Landis, unpublished observations). Although the time course of appearance of catecholaminergic properties has been well-described, the mechanisms responsible for their induction and regulation in developing sympathetic neurons and chromaffin cells in vivo are unclear. Primary induction of TH appears to be influenced by the migration route which the neural crest cells follow to the ganglion or by the local ganglionic environment (Cohen, 1972; Norr, 1973; LeDourain and Teillet, 1974; Teillet et al., 1978; Howard and Bronner-Fraser, 1985, 1986). Once TH is expressed, nerve growth factor (NGF; Thoenen et al., 1971; Otten et al., 1977; Max et al. 1978), cell contact (Acheson and Thoenen, 1983), and impulse activity (Mueller et al., 1969a, b; Joh et al., 1973; Zigmond, 1985) influence levels of the enzyme. Subsequent to the arrival of the last precursors in the adrenal gland, a subpopulation of chromaffin cells expresses phenylethanolamine $N$-methyltransferase (PNMT; Bohn et al., 1981), the enzyme that catalyzes the conversion of noradrenaline to adrenaline. The mechanism responsible for the initial induction of PNMT in chromaffin cells is unknown, although glucocorticoids produced by adrenal cortical cells regulate the levels of PNMT subsequently (Wurtman and Axelrod, 1966; Bohn et al., 1981; Teitelman et al., 1982; Grothe et al., 1985).

While the appearance of adrenergic traits in the sympathoadrenal lineage is well documented and regulatory mechanisms have been postulated, relatively little is known about the expression and regulation of peptidergic properties during development. There have been few reports of the timing of initial peptide expression in this lineage; for example, it is not known when 
neuropeptides first appear in rat adrenal chromaffin cells. Developmental studies of neuropeptide expression by sympathoadrenal cells in chick and quail provide evidence that some of the peptides examined appear to be expressed early and that the number of cells expressing a particular peptide varies during development (Fontaine-Perus et al., 1982; Hayashi et al., 1983; Maxwell et al., 1984; Garcia-Arraras et al., 1984, 1987; New and Mudge, 1986).

As a first step in determining the cellular and molecular mechanisms that determine neuropeptidergic phenotypes of sympathoadrenal derivatives of mammalian neural crest, we have examined the developmental expression of NPY and L-Enk in rat adrenal chromaffin cells using immunocytochemical techniques and compared it to the expression of PNMT. Adrenal chromaffin cells are well suited for investigating neuropeptide expression because subpopulations of mature rat adrenal chromaffin cells are known to synthesize the neuropeptides NPY and L-Enk (Schultzberg et al., 1978; Bohn et al., 1983; de Quidt and Emson, 1986; Schalling et al., 1988), and comparisons can be made with the development of catecholamine properties in the same cells. In addition, peptide expression in chromaflin cells, in contrast to sympathetic neurons, is uncomplicated by possible modulation by interactions with target tissues. We have found that neuropeptides and PNMT are expressed early in embryonic development and that the proportions of peptide containing chromaffin cells are much greater during late embryonic development than during early embryonic development and in the adult. The timing and pattern of expression of neuropeptides during development suggest that the local environment influences the primary induction and subsequent regulation of neuropeptides in adrenal chromaffin cells.

\section{Materials and Methods}

Animals. Timed pregnant, newborn, and adult Sprague-Dawley rats were obtained from Zivic-Miller (Zelienople, PA). Embryos were considered to be embryonic day 0.5 on the morning after a midnight breeding. Additionally, at the time of death, embryos were staged by cxamination of external features according to Christie (1962). Rats of both sexes weighing $200-250 \mathrm{gm}$ were used in experiments on adult rats. Adrenal glands from embryos were dissected quickly and immersionfixed for $1.5 \mathrm{hr}$ at room temperature in $4 \%$ paraformaldehyde in $0.1 \mathrm{M}$ phosphate buffer, $\mathrm{pH}$ 7.4. Newborn and adult rats were killed by ether inhalation and perfused through the heart with phosphate-buffered paraformaldehyde for $10 \mathrm{~min}$ at room temperature. After perfusion, the adrenal glands were removed and further fixed in the paraformaldehyde solution for $50 \mathrm{~min}$. The tissues were then rinsed in $0.1 \mathrm{M}$ phosphate buffer and equilibrated in 30\% sucrose in phosphate buffer for 12-24 hr at $4^{\circ} \mathrm{C}$. Adrenal glands were frozen individually onto cryostat chucks with O.C.T. compound (Miles Laboratories). Seven micron cryostat sections were cut, mounted on gelatin-coated slides, and processed for immunocylochemistry.

Antisera. Several antisera that recognize neuropeptides were used. In many experiments, the peptide antisera employed had been raised in rabbits and were obtained commercially. NPY antiserum was purchased from Amersham (Arlington Heights, IL) and L-Enk antiserum from Incstar (Stillwater, MN). The commercial peptide antisera exhibited no specific labeling in tissue sections when preincubated with the appropriate peptide antigen ( $10 \mu \mathrm{g} / \mathrm{ml}$ for L-Enk; $50 \mu \mathrm{g} / \mathrm{ml}$ for NPY). L-Enk and M-Enk peptides were obtained from Peninsula Laboratories (Belmont, CA). The L-Enk antiserum cross-reacted to a small extent with methionine-enkephalin peptide as assessed by a slight decrease in the intensity of staining in tissue sections when the primary antiserum was preincubated with this peptide. Since tissue sections of adult adrenal glands exhibited no specific staining when incubated with a M-Enkspecific antiserum (Incstar), it seems likely that the enkephalin immunoreactivity revealed with the L-Enk antiserum is that of L-Enk. For colocalization studies, we generated a guinea pig antiserum against por- cine NPY (Peninsula Laboratories) which was conjugated to keyhole limpet hemocyanin via a glutaraldehyde linkage. The reactivity of the guinea pig antiserum for NPY was tested by dot blot and ELISA analysis. The antiserum recognized human NPY (Peninsula) at dilutions up to $1: 100,000$. Preincubation of the antiserum at a dilution of $1: 100$ with $25 \mu \mathrm{g} / \mathrm{ml}$ of NPY completely blocked the recognition of NPY in ELISA assays. Staining in sections of various tissues, including adrenal gland and superior cervical ganglion, was identical to that observed with the commercial NPY antiserum, and all specific staining of the tissue sections was eliminated by preincubation of the antiserum with $50 \mu \mathrm{g} / \mathrm{ml}$ of NPY.

Antisera that recognized transmitter synthetic enzymes were obtained from several sources. A monoclonal antibody that recognized TH (generous gift of A. Acheson, University of Alberta, Edmonton) was raised against TH purified from the rat pheochromocytoma line (Rohrer et al., 1986). Identical results were obtained with a TH antiserum (generous gift of J. Thibault, College de France, Paris) that was raised in rabbit against TH purified from the rat pheochromocytoma line (Thibault et al., 1981). The PNMT antiserum was obtained from Eugene Tech (Allendale, NJ). The ChAT antiserum (generous gift of M. Epstein, University of Wisconsin-Madison, Madison, WI) was generated in rabbit against ChAT purified from chicken brain (Johnson and Epstein, 1986). A mouse monoclonal antibody to neurofilament $160 \mathrm{kDa}$ (NFl60) was obtained from Sigma.

The following secondary antisera were used in various experiments: tetramethylrhodamine isothiocyanate-conjugated goat anti-rabbit (Tago; Burlingame, CA), fluorescein isothyocyanate-conjugated goat anti-mouse and goat anti-guinea pig (Antibodies Incorporated, Davis, CA), biotinylated goat anti-guinea pig (Vector Laboratories, Burlingame, CA), streptavidin-Texas Red (Amersham), and 7-amino-4-methylcoumarin3-acctic acid (AMCA)-conjugated goat anti-rabbit (Jackson ImmunoResearch). These secondary antisera were chosen on the basis of their specificity of reactivity with primary antisera of the same species. Each secondary antiserum was tested on tissue sections labeled with primary antisera of the other species. For example, the goat anti-mouse FITC was incubated with adrenal sections labeled with a primary antiserum generated in rabbit and sections labeled with a primary antiserum generated in guinea pig. No reactivity of any of the secondary antisera listed above was observed with primary antisera of an inappropriate species.

Light microscopic immunocytochemistry. Cryostat sections were processed for indirect immunofluorescence according to the method of Coons (1958). Briefly, sections were incubated with antiserum to NPY, L-Enk, PNMT, or ChAT or with the TH or NFI 60 monoclonal antibody in a humid chamber for 12-24 hr. All antisera were diluted in a buffer containing $0.5 \mathrm{M} \mathrm{NaCl}, 0.01 \mathrm{~m}$ phosphate buffer, $\mathrm{pH} 7.3,0.1 \%$ sodium azide, and $5 \%$ BSA. After incubation with a primary antiserum or antibody, the sections were rinsed in PBS and incubated with a speciesappropriate secondary antiserum diluted in the same buffer used for dilution of primary antisera for $2 \mathrm{hr}$ at room temperature in a humid chamber. Sections incubated with biotinylated goat anti-guinea pig antiserum were washed in PBS and incubated for $1 \mathrm{hr}$ at room temperature in streptavidin-Texas red. The sections were then rinsed in PBS, mounted in glycerin/PBS (1:1), and examined with a Zeiss microscope equipped with epifluorescence and rhodamine, fluorescein, and True blue filter sets.

Double- and triple-labeling experiments. The proportions of chromaffin cells expressing NPY, L-Enk, or PNMT were determined using double-label immunocytochemical techniques at various times during development. Since all chromaffin cells contain TH, it was possible to label the entire chromaffin cell population with the TH monoclonal antibody. Because the antisera against NPY, L-Enk, and PNMT were raised in rabbit, sections were incubated with one of these antisera and subsequently with the TH monoclonal antibody; labeling of the different primary antisera was detected with appropriate secondary antisera conjugated to distinct fluorophores. Routinely, sections were incubated overnight with either a peptide or the PNMT antiserum, rinsed in PBS, and incubated with rhodamine-conjugated goat anti-rabbit secondary antiserum for $2 \mathrm{hr}$. After incubation in the first secondary, sections were rinsed in PBS and incubated with the TH monoclonal antibody for $0.5-$ $12 \mathrm{hr}$, rinsed in PBS, and incubated with fluorescein-conjugated goat anti-mouse antiserum for $0.5-2 \mathrm{hr}$, rinsed in PBS and mounted. Entire sections of the adrenal gland wcrc randomly selected and photographed with both excitation conditions. Photographic montages were made which represented the entire section and cells were counted using a 1 
$\mathrm{cm}^{2}$ grid. At least 3 sections stained for each antigen at each age were counted. TH-immunoreactive (IR)-chromaffin cells at the intersection of grid lines were counted as positive or negative for a particular antigen and expressed as a percentage of the total number of sampled cells (percent, TH-positive cells).

The possible coexistence of NPY, L-Enk, and PNMT in subpopulations of TH-IR chromaffin cells was examined by double- and triplelabeling frozen tissue sections with different combinations of antisera or antibody elution experiments. Double- and triple-labeling experiments were performed in 1 of 2 ways. In some experiments, tissue sections were incubated sequentially in antiserum combinations as described above with the addition of sets of primary and secondary antisera in succession for a total of 2 or 3 different sets. In the other experiments, tissue sections were incubated with a solution containing 2 or 3 primary antisera each generated in a different species overnight at room temperature, washed, and incubated with 2 or 3 secondary antisera, each conjugated to a different fluorophore and distinguished with separate filter sets. Cell counts were performed as described above. Comparable results were obtained with both methods. Antibody elution experiments, according to the method of Tramu et al. (1978), were performed when different antisera were raised in the same host species. Briefly, sections were labeled with the peptide antiserum and appropriate secondary antiserum and photographed. The sections were then rinsed in a solution of $5 \% \mathrm{H}_{2} \mathrm{SO}_{4}$ and $3 \%$ potassium permanganate. Control sections were analyzed in 2 ways for each experiment in order to determine the appropriate elution time. First, after the elution, sections were examined for any remaining fluorescence due to residual secondary antiserum. Second, postelution sections were reincubated with the secondary antiserum and examined for specific fluorescence to ensure complete elution of the primary antiserum.

\section{Results \\ Colocalization of neuropeptides and PNMT in adult chromaffin cells}

The neurochemical properties of chromaffin cells were first characterized in adult animals. Approximately $85 \%$ of adult chromaffin cells were found to contain PNMT-IR, while 40 and 10\% were NPY-IR and L-Enk-IR, respectively (Fig. 1). The intensity of NPY and L-Enk-IR was highly variable from cell to cell in the adult. To examine whether NPY and L-Enk were colocalized with PNMT and therefore expressed in the epinephrine-synthesizing population of cells, antibody elution and double-label studies were performed. Elution experiments showed that NPYIR cells were also PNMT-IR in all sections examined. Likewise, PNMT-IR was observed in all L-Enk-IR cells (Fig. 2). Because of the nature of the elution procedure, a small number of peptide-positive and PNMT-negative cells might have been overlooked. This is unlikely, however, since the proportions of peptide- and PNMT-IR cells evident after the elution were virtually identical to those in pre-elution control sections.

To examine the possible coexistence of peptides and PNMT more directly, an antiserum directed against NPY was generated in guinea pig. Double-labeling experiments showed that, in agreement with elution experiments, NPY-IR cells were always PNMT-IR (Fig. 1). NPY and L-Enk were not preferentially colocalized, although NPY was found to be present in about one-third of the L-Enk-IR population (Fig. 1). Thus, in the adrenal of normal adult rats, the neuropeptides NPY and L-Enk are restricted to the epinephrine-synthesizing population of chromaffin cells. Within the PNMT-IR population, NPY and L-Enk are evident in distinct subpopulations of cells and are colocalized in only a small proportion of the PNMT-IR population. In contrast, norepinephrine, or PNMT-negative chromaffin cells, do not contain detectable levels of either neuropeptide.

\section{Morphological development of the adrenal gland}

On E15, the earliest time examined, precursor cells migrating from the sympathetic ganglion primordium were observed entering the forming adrenal gland. In the adrenal gland they established 2 morphologically distinguishable classes of cells which remained distinct throughout embryonic development. In the medial portion of the gland, large clusters of densely packed TH-IR cells were evident, while more laterally TH-IR cells were present either alone or in small groups (Fig. 3). Many cells, particularly in the lateral portion of the gland, appeared to extend 1 or 2 short, thick processes, often in a bipolar manner. Medially, most cells within the large clusters were rounder and lacked processes. In addition, the clustered cells consistently exhibited less intense TH-IR than did nonclustered cells (Fig. 3).

With further embryonic development of the adrenal gland, the chromaffin precursor cells reorganized within the gland to form the medulla and the extraadrenal ganglionic complex (EAGC) formed a discrete structure where the chromaffin precursor cells appeared to enter the gland. On E16, individual, grouped, and clustered TH-IR cells were scattered throughout the forming gland with no obvious topographic organization. The FAGC was well defined and separate from the forming gland, exterior to the capsule. Chromaffin cells were first observed to occupy the central and eventual medullary region preferentially on E17-18. Clustered and nonclustered TH-IR cells were generally uniform in their morphological appearance at this time, being oval-shaped and lacking processes. Large clusters of closely packed cells were usually found in the central region of the gland. On E19-20, a small number of large NPYIR, TH-negative cells with processes was observed. Small groups of such cells are present in the adult medulla, and it has been suggested that they are cholinergic parasympathetic neurons (Coupland, 1972; Aloe and Levi-Montalcini, 1980; Schalling et al., 1988). By birth, the precursor cells were organized into a defined medulla, and the large, distinct clusters appeared more elongated and less densely packed. Clusters could no longer be distinguished on the seventh postnatal day $(P)$. The medulla appeared uniform in cell type at this time with the exception of the occasional large TH-negative neurons and dispersed groups of cortical cells. Other than an increase in cell size, the general appearance of the gland did not change with further development.

\section{Neuropeptide and PNMT expression during adrenal development}

NPY-IR cells were present on E1 5 in the forming adrenal gland and EAGC as soon as chromaffin precursors began to invade (Fig. 3). At this age, approximately half of the TH-IR cells in the adrenal exhibited granular NPY-IR. The densely packed cells in the medial portion of the gland were consistently NPYIR, whereas few of the more dispersed and lateral TH-IR cells wcre positive. In addition, the medial clusters of NPY-IR cells exhibited less intense TH-IR than did the more lateral population of cells. A small increase in the proportion of NPY-IR chromaffin cells occurred between E15 and E16. At E16, intensely NPY-IR clusters of cells were present throughout the gland, and the clustered cells appeared to be more spherical and less intensely TH-IR. Although most of the TH-IR cells outside of the dense clusters in the adrenal proper were NPY negative or weakly NPY-IR, a small number exhibited intense NPY-IR. 

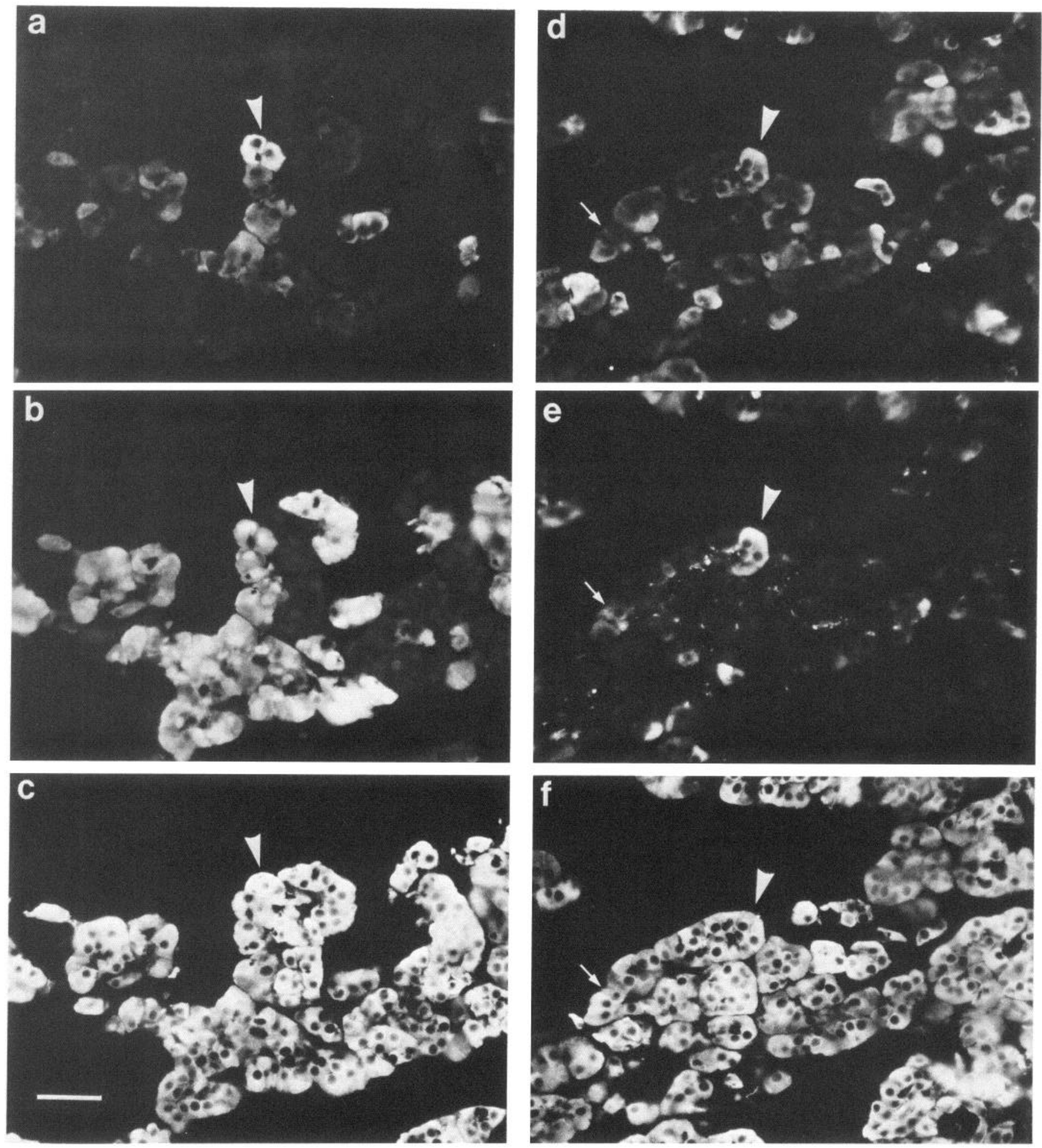

Figure 1. Localization of neuropeptide immunoreactivities in adult chromaffin cells. The colocalization of immunoreactivities for NPY, L-Enk, and catecholamine synthetic enzymes was examined using triple-label immunocytochemistry. NPY-IR $(a)$ is present in approximately $40 \%$ of the TH-IR cells $(c)$ and is localized exclusively in PNMT-IR cells $(b$, arrowheads). L-Enk-IR $(e)$ is present in $10-15 \%$ of the TH-IR cells $(f)$. L-EnkIR is present in NPY-IR cells ( $d$, arrowheads), as well as NPY-negative cells (arrow). Scale bar, $50 \mu \mathrm{m}$. 

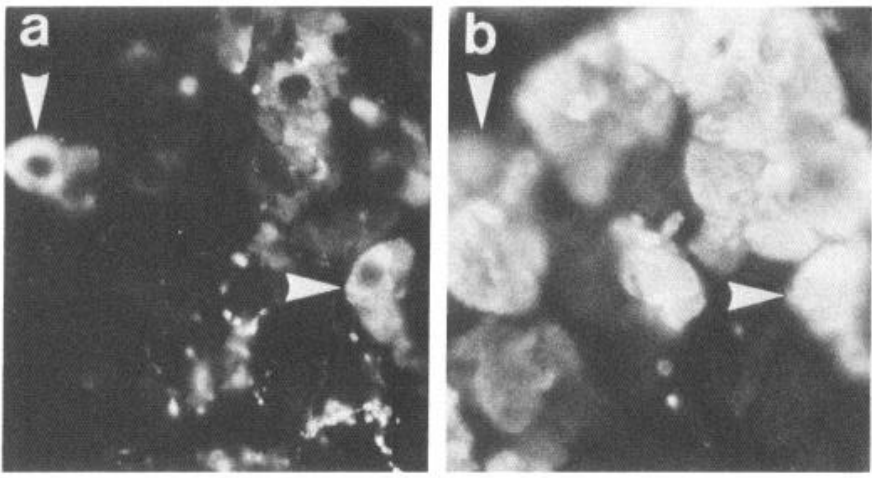

Figure 2. Double labeling by antibody elution for L-Enk and PNMT in a single section of adult adrenal medulla. L-Enk-IR ( $a$, arrowheads) is restricted to PNMT-IR cells ( $b$, arrowheads). Scale bar, $20 \mu \mathrm{m}$.

In the EAGC, approximately half of the cells were NPY-IR. Like the clustered cells in the gland, NPY-IR cells exhibited weak TH-IR, while NPY-negative cells were intensely TH-IR.

The proportion of NPY-IR precursor cells increased from about half at E15 to approximately $80 \%$ on E20 (Fig. 4). As development proceeded, a greater proportion of cells not present in large clusters were moderately immunoreactive; very few of these cells, however, exhibited immunofluorescence equal to that of the cells present in large clusters in the gland or in the EAGC. At all times during embryonic development, the intensity of NPY-IR in nonclustered cells was variable, while nonclustered cells were invariably intensely TH-IR. Most cells in the large clusters exhibited TH-IR that was only slightly above background, although typically a small number of cells along the perimeter of the clusters were intensely TH-IR (Fig. 4). The inverse relationship between the intensities of NPY- and THIR was equally pronounced in the well-delineated EAGC. Between E18 and birth, the proportion of NPY-IR cells remained virtually constant.

After birth, there was a significant decrease in proportion of chromaffin cells exhibiting NPY-IR. By the third postnatal day, a large proportion of NPY-IR cells possessed immunofluorescence only slightly above background and were considered NPYnegative. The proportion of chromaffin cells expressing NPY decreased to approximately $40 \%$, the proportion of NPY-IR cells evident in the adult medulla, by the end of the first postnatal week. No uniformly NPY-IR groups or clusters of cells were observed at any time after P7 (Fig. 1). In addition to the changes observed in the proportion of NPY-IR cells, the appearance of the NPY-IR in cells changed. The intensity was variable from cell to cell, and the immunoreactivity appeared less granular than in embryonic chromaffin cells.

L-Enk-IR appeared later in chromaffin precursor cells than did NPY-IR. No L-Enk-IR precursor cells were observed on E15 in the adrenal proper or in the EAGC. Occasional TH-IR cells were L-Enk-IR on E16 in the gland (Fig. 5), while only rarely were L-Enk-IR cells observed in the EAGC; typically these were located at the border of the gland and EAGC. L-Enk-IR cells in both the adrenal and the EAGC were always intensely TH-IR and not present in clusters, in contrast to the NPY-IR cells in the EAGC. The L-Enk-IR cells exhibited a punctate pattern of staining and were usually irregular in shape with 1 or 2 short processes.

After the initial appearance of L-Enk-IR in a small proportion
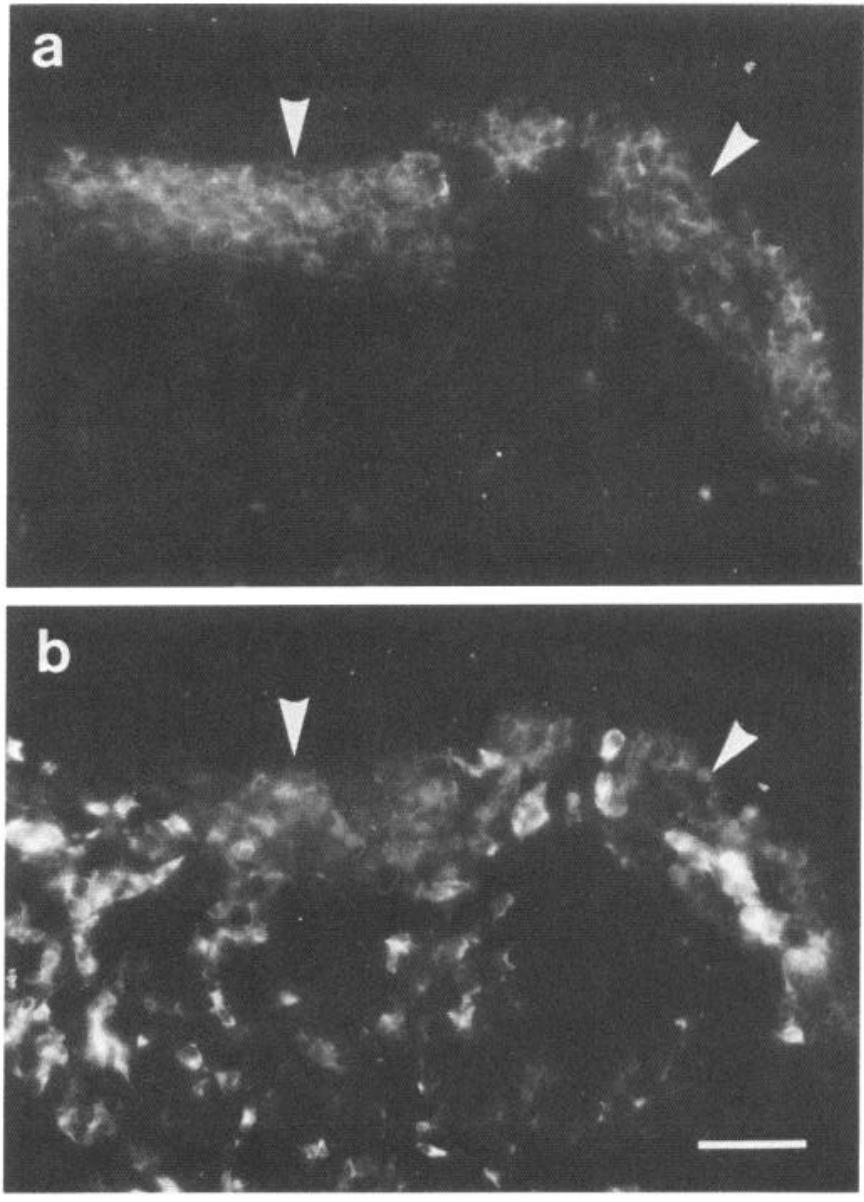

Figure 3. NPY and TH double-label immunocytochemistry in E15 adrenal gland. Clustered NPY-IR cells $(a)$ are present in the medial aspect of the forming adrenal gland (arrowheads). NPY-IR cell clusters exhibit less intense TH-IR ( $b$, arrowheads) compared with nonclustered cells present in the more lateral portion of the gland. Scale bar, $50 \mu \mathrm{m}$.

of cells on E16, striking changes occurred in L-Enk expression. The proportion of L-Enk-IR cells increased to about $40 \%$ by E20 (Fig. 6). Small groups, pairs, and individual cells were labeled, while the cells within the large clusters remained negative. The staining intensity of L-Enk-IR was variable from cell to cell. The proportion of cells remained constant until birth. Subsequently, the proportion of intensely L-Enk-IR cells decreased to approximately $10 \%$ by the second postnatal day and remained constant thereafter. Staining intensity varied from moderate to intense in the early postnatal and adult adrenal, and no obvious grouping of positive cells was evident (Fig. 1).

In contrast to NPY but like L-Enk, no PNMT-IR cells were observed on E15. PNMT-IR cells were first observed on E16 in approximately $35 \%$ of the TH-IR chromaffin cell population (Fig. 7). By E18, the proportion of PNMT-IR cells had increased to approximately $70 \%$. PNMT-IR cells were absent not only from the EAGC, but also from the large clusters of cells in the adrenal gland at all times during development (Fig. 4). On P7, when large clusters of cells were no longer evident, the proportion of PNMT-IR cells represented approximately $85 \%$ of the chromaffin cell population, equivalent to adult values (Fig. 1).

Although in the adult, NPY or L-Enk was found to be colocalized with PNMT in subpopulations of chromaffin cells, during embryonic development, NPY and PNMT were not always 

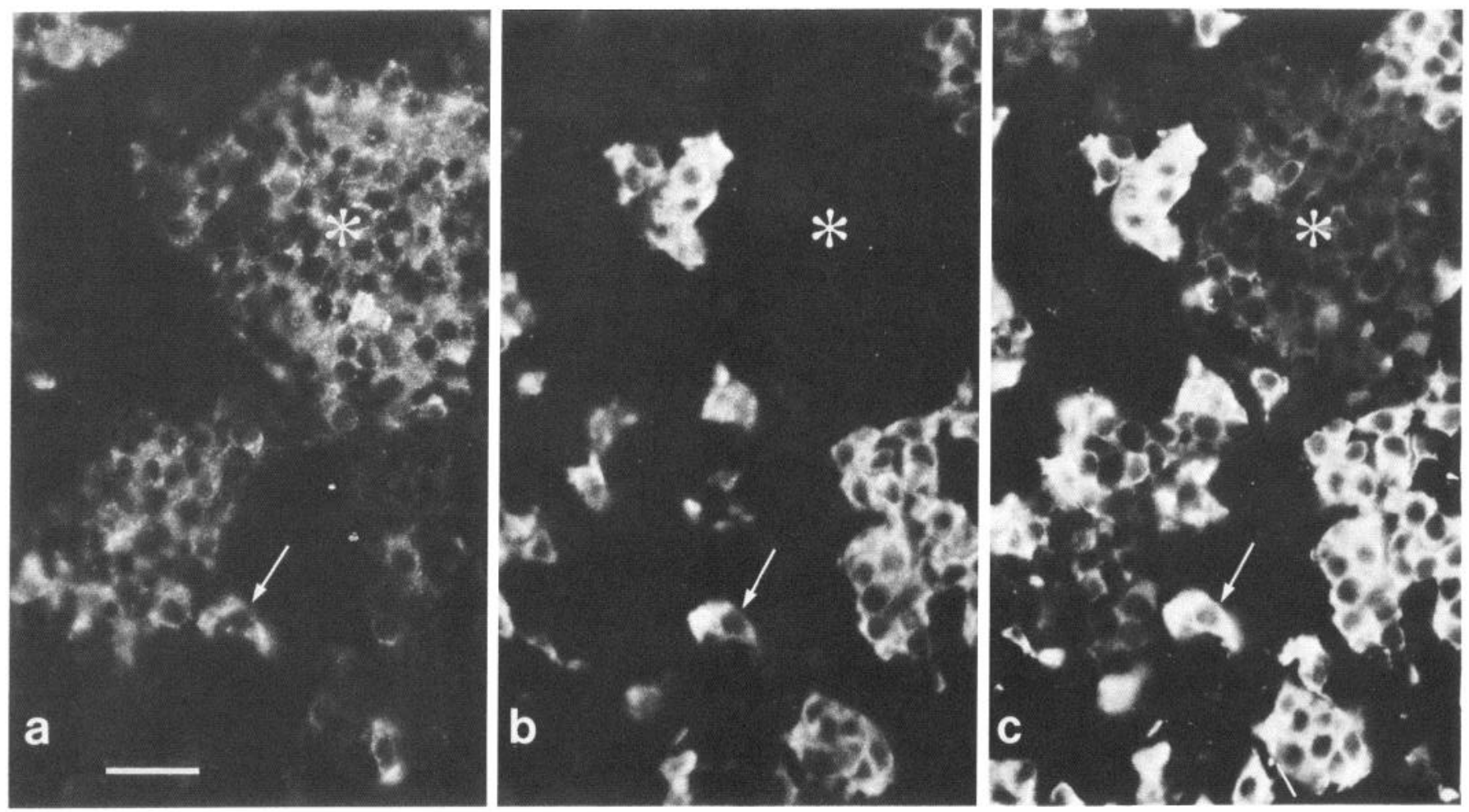

Figure 4. Triple immunocytochemical labeling of E20 adrenal gland for NPY, PNMT, and TH. Intense NPY-IR cells ( $a$ ) were observed predominantly in large cell clusters (asterisk), although many nonclustered cells also exhibited NPY-IR (arrow). PNMT-IR (b) was never observed in cell clusters (asterisk); most nonclustered cells, however, were PNMT-IR (arrow). Clustered cells exhibited less intense TH-IR (c) than nonclustered cells (arrow). Scale bar, $25 \mu \mathrm{m}$.

colocalized. NPY was detectable at least a full day before PNMT. Furthermore, a large number of NPY-IR cells were present in the large clusters within the adrenal and extraadrenal ganglionic complex, while these same cells were PNMT-negative at all times during embryonic development. Conversely, L-Enk and PNMT appeared to be colocalized during embryonic development in the adrenal, but not in the EAGC; occasional L-EnkIR cells were present in the EAGC, while no PNMT-IR cells were observed there. PNMT-IR and L-Enk-IR cells were first evident on E16, and the pattern of their expression was similar during development. PNMT-IR and L-Enk-IR cells were distributed throughout the forming adrenal but were never observed in the large clusters of cells.

\section{Appearance of ChAT-IR and L-Enk-IR in the preganglionic innervation of the adrenal}

To determine when chromaffin cells are initially innervated by preganglionic fibers, we examined tissue sections of adrenals from E15 to P14 for 2 markers, ChAT and L-Enk, that characterize the adult innervation. Mature adrenal chromaffin cells are innervated by cholinergic preganglionic sympathetic fibers from the splanchnic nerve. Most of these fibers also exhibit L-Enk-IR as determined by antibody elution experiments (data not shown), consistent with published results (Schultzberg et al., 1978). No ChAT-IR fibers were observed during embryonic development. Weakly fluorescent ChAT-IR fibers were first apparent on P2, and their number and the intensity of their labeling increased steadily until P14, at which time the innervation closely resembled that of adult animals (Fig. 8). As with ChAT-IR, no L-Enk-IR fibers were observed during embryonic development.
Very faint L-Enk-IR fibers were present on P5. The intensity of L-Enk-IR fibers, however, was not equivalent to the adult until P11-12 (see Fig. 1). While no ChAT or L-Enk-IR fibers were observed in embryonic adrenals, bundles of fibers were observed on E15-P0 that were labeled with antibodies to neurofilament $160 \mathrm{kDa}$ (not shown). These fibers, however, were always present in bundles and did not appear to be associated with either TH-IR or any other cells in the gland. On E18-P0, NF160-IR fibers appeared to be more dispersed in the gland, although no obvious terminals on chromaffin cells were observed until P2. Thus, the normal pattern of preganglionic innervation does not appear to be established in the adrenal gland until after birth.

\section{Discussion}

Chromaffin cells in the adrenal medulla of the adult rat exhibit several different neurochemical phenotypes. Most chromaffin cells, approximately $85 \%$, produce epinephrine as indicated by immunoreactivity to antibodies against PNMT, while the remaining chromaffin cells produce norepinephrine. These proportions are consistent with published reports (Hillarp and Hökfelt, 1953; Eranko, 1955; Coupland, 1965; Doupe et al., 1985). In addition, subsets of chromaffin cells in the adult contain the neuropeptides, NPY and L-Enk. Using antibody elution and double- and triple-label immunocytochemical techniques, we have found that L-Enk-containing cells are restricted to the PNMT-IR chromaffin cell population in the adult rat as previously described in bovine and hamster adrenal (Livett et al., 1982; Pelto-Huikko et al., 1982). We found that $10-15 \%$ of the cells in adult rats contained L-Enk, in contrast to previous reports (Bohn et al., 1983). When guinea pig anti-NPY and 

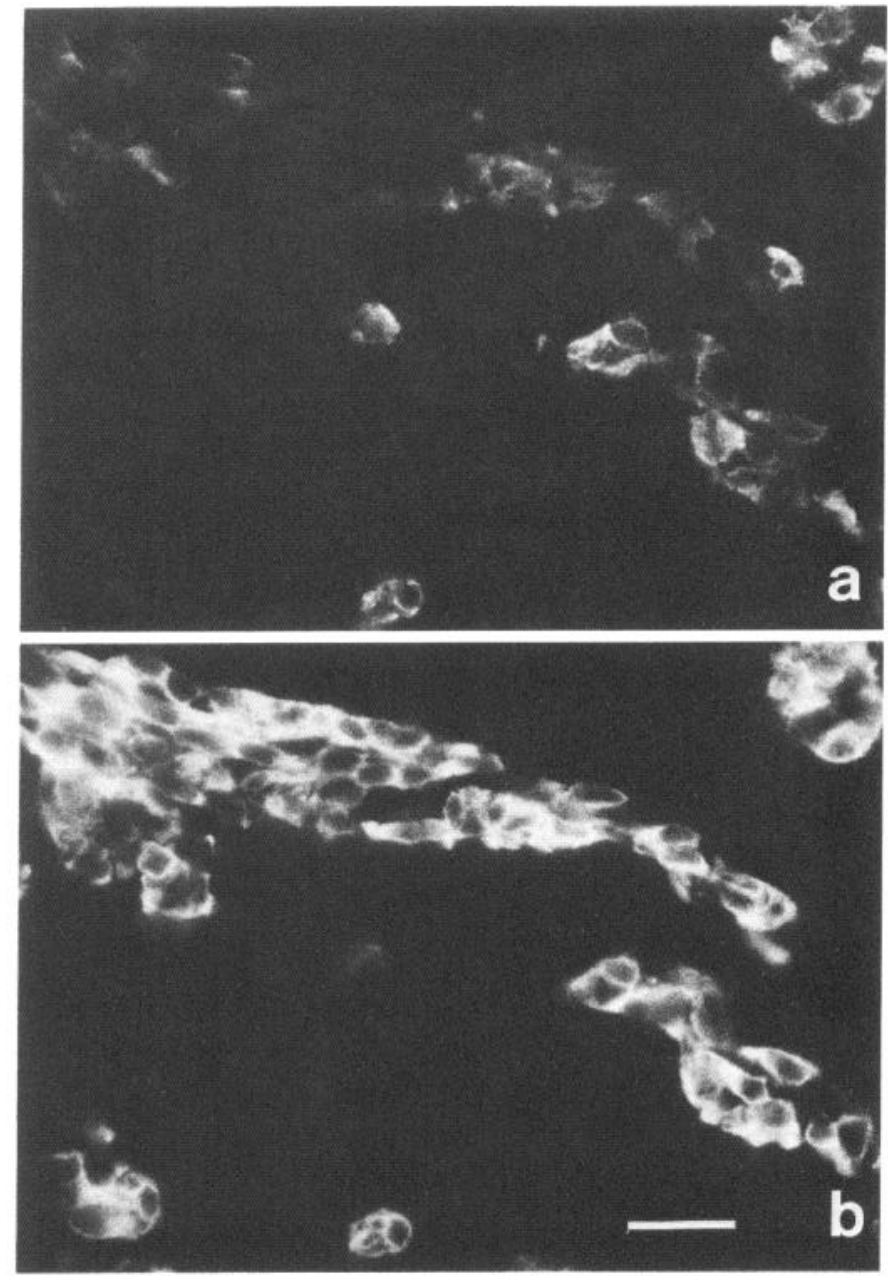

Figure 5. Double immunocytochemical labeling of E16 adrenal gland for L-Enk and TH. L-Enk-IR cells $(a)$ were first detectable at this time and L-Enk-IR was present in approximately $10 \%$ of the TH-IR cells at this age $(b)$. Scale bar, $20 \mu \mathrm{m}$.

rabbit anti-PNMT were used on the same tissue section, NPYIR was evident in a subset of PNMT-IR cells. Our findings contrast with those of a previous study (Schalling et al., 1988) in which NPY-IR was localized in both PNMT-IR and PNMTnegative cells when adjacent sections were analyzed. This discrepancy may result from the difficulty in relocating unambiguously the same chromaffin cell in adjacent sections or from the use of different antiserum dilutions. Although both L-Enk and NPY are restricted to the PNMT-IR population, these peptides are not always colocalized. Approximately one-third of the L-Enk-IR cells exhibited NPY-IR. These results indicate that there are at least 5 phenotypically distinct subpopulations of adult rat chromaffin cells defined immunocytochemically. Approximately $15 \%$ of the cells synthesize predominantly norepinephrine. The remaining $85 \%$ of the chromaffin cells synthesize predominantly epinephrine. In addition, of these cells, approximately $40 \%$ contain NPY and $10-15 \%$ contain L-Enk. A small subpopulation of PNMT-IR cells contain both NPY and L-Enk.

The adult complement of cell classes appears to be acquired through a complicated developmental process of neurochemical induction and regulation. NPY was present in a large proportion of cells at E15, the earliest time examined. L-Enk and PNMT, however, were not detected until E16. The proportions of NPY-,
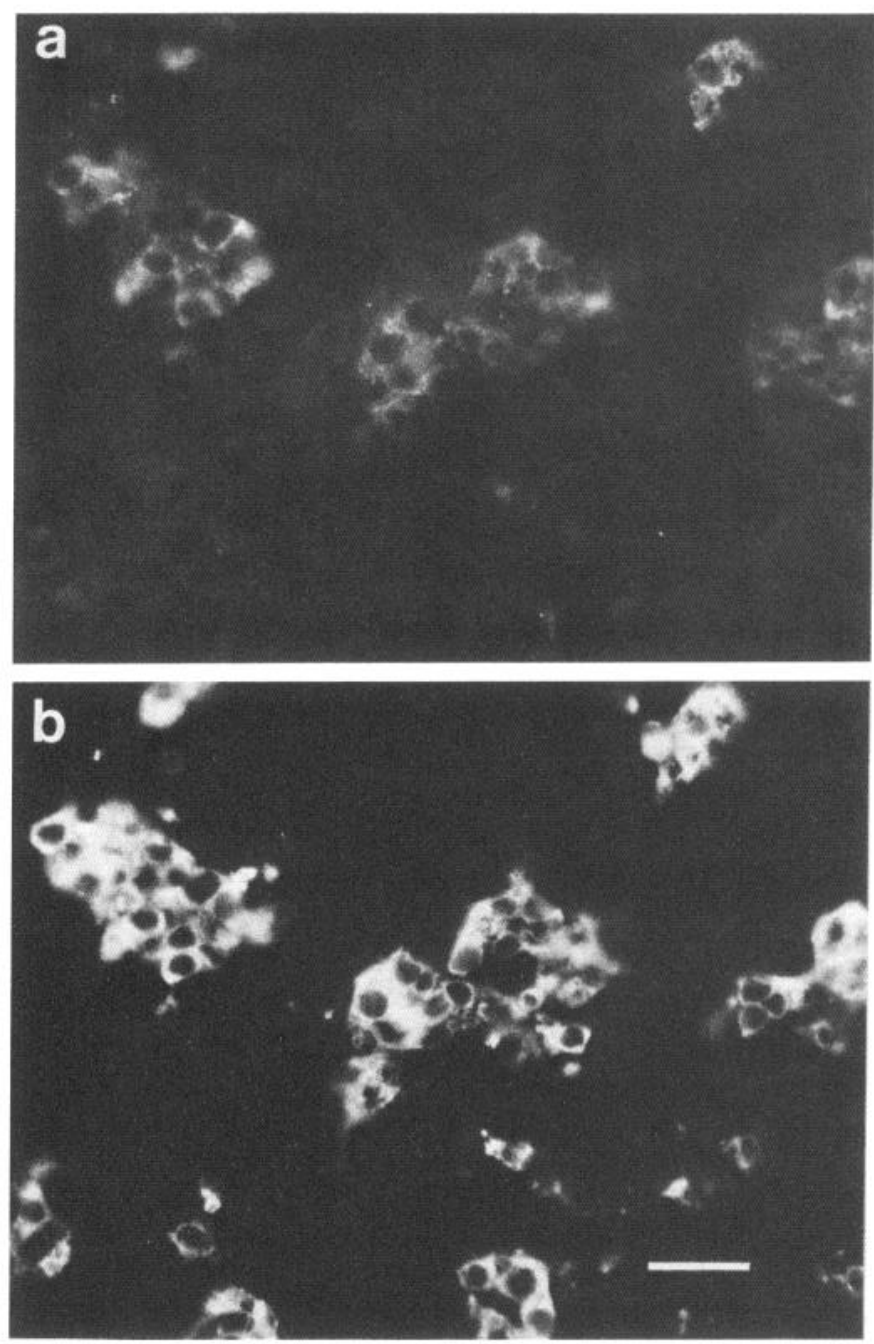

Figure 6. Double immunocytochemical labeling of E20 adrenal gland for L-Enk and TH. L-Enk-IR (a) was present in approximately $40 \%$ of the TH-IR cells at this age $(b)$. Scale bar, $25 \mu \mathrm{m}$.

L-Enk-, and PNMT-positive TH-IR cells increased dramatically between E16 and E20 and remained relatively constant until birth. The proportions of NPY- and L-Enk-containing chromaffin cells on E20-P0 were 2 and 4 times greater, respectively, than in the adult. During the first postnatal week the proportions of NPY - and L-Enk-IR chromaffin cells decreased dramatically to adult values, while the proportion of PNMT-IR cells increased slightly to reach adult values.

The finding that NPY was present in approximately half of the TH-IR cell population on E15, while L-Enk and PNMT were not detected until E16 and then only in a small proportion of cells suggests that the mechanisms responsible for the induction of NPY are different than those for L-Enk and PNMT. On E15, numerous NPY-IR cells were observed in the sympathetic ganglion primordium from which the cells migrate, the presumptive migration route, the EAGC and the medial portion of the adrenal. Thus, in contrast to L-Enk and PNMT, the induction of NPY in precursor cells occurs before cells invade the adrenal gland, and the local environment of the adrenal gland does not appear to be necessary for the initial expression of NPY. It seems likely that environmental factors present along the primary neural crest migration route or in the forming sym- 

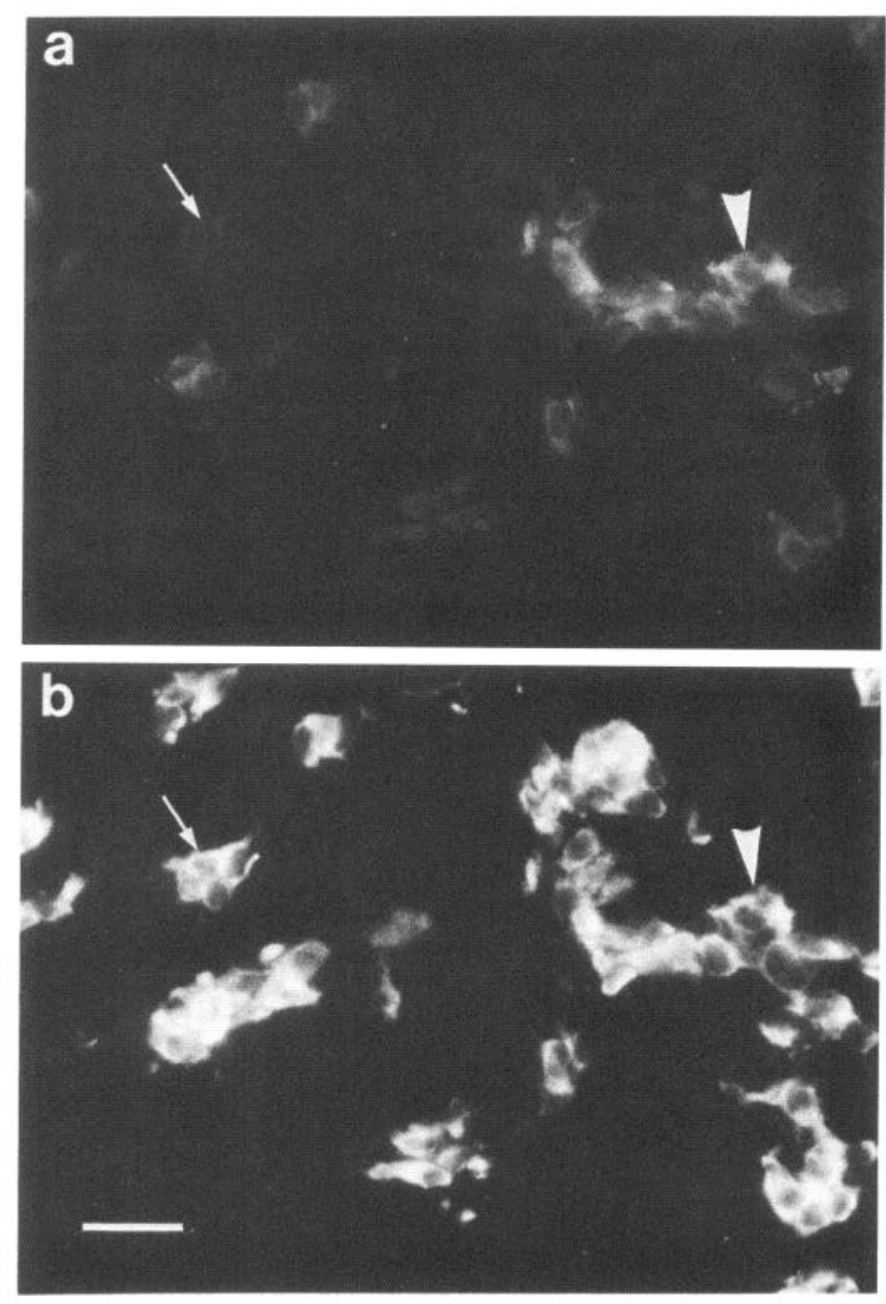

Figure 7. Double immunocytochemical labeling of E16 adrenal gland for PNMT and TH. PNMT-IR cells $(a$, arrowhead $)$ were first detectable at E16. In contrast to later developmental stages, numerous PNMTnegative, TH-IR cells were present at this time $(b$, arrows $)$. Scale bar, $25 \mu \mathrm{m}$.

pathetic ganglion result in NPY induction in sympathoadrenal precursor cells, some of which eventually migrate to and reside in the adrenal gland. The induction of catecholaminergic properties has previously been attributed to the migratory route and/ or ganglionic environment (Cohen, 1972; Norr, 1973; LeDourain and Teillet, 1974; Teillet et al., 1978; Howard and Bronner-Fraser, 1985, 1986). It is possible that the same factors are responsible for the induction of both TH and NPY. At the time of arrival of precursor cells in the adrenal, however, only half of the TH-IR cells express NPY-IR. If a common factor is responsible for the appearance of both, then there may be a differential lag between induction and expression of the 2 properties. Alternatively, the possibility exists that the NPY-negative chromaffin cell precursors might derive from cells which are initially NPY-positive and subsequently lose this property. The loss of another phenotypic marker, neurofilament-IR, by chromaffin cell precursors has previously been shown in culture studies (Anderson and Axel, 1986). A final possibility is that distinct signals with a similar developmental program could induce TH and NPY.

In contrast to TH and NPY, the initial expression of PNMT
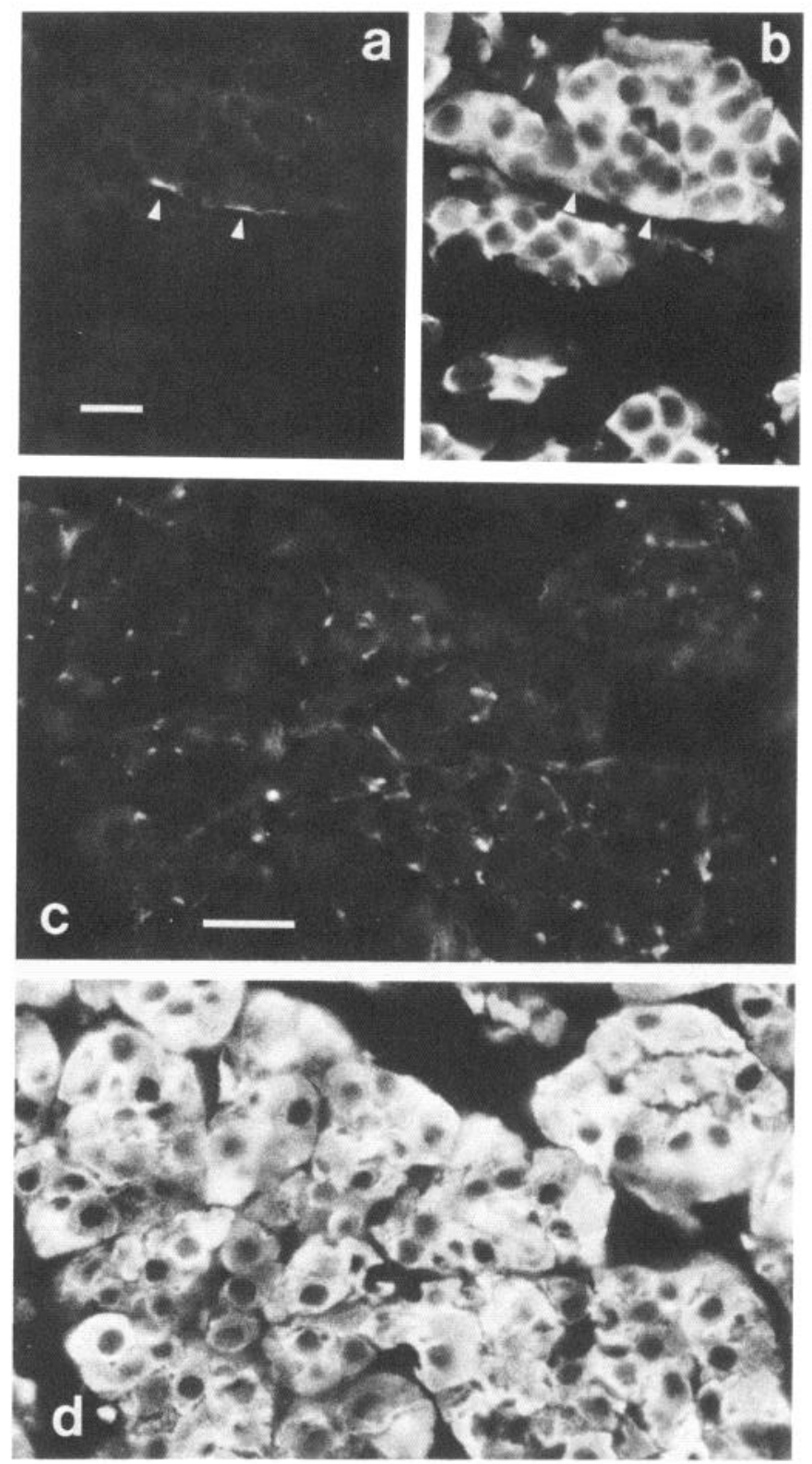

Figure 8. Double immunocytochemical labeling of $\mathrm{P} 2(a, b)$ and adult $(c, d)$ adrenal for ChAT and TH. Sparse ChAT-IR preganglionic fibers $(a$, arrows $)$ were first detectable on $\mathrm{P} 2$ and appeared to be associated with TH-IR cells $(b$, arrows). The number and intensity of ChAT-IR fibers increased during postnatal development until P14, when the pattern of ChAT-IR $(c)$ with respect to TH-IR cell bodies $(d)$ was very similar to the adult. Scale bar $15 \mu \mathrm{m}(a), 25 \mu \mathrm{m}(c)$.

and L-Enk occurs after precursor cells arrive in the adrenal gland and is temporally correlated with the large increase in the production of glucocorticoids by adrenal cortical cells on E16 (Siedl and Unsicker, 1989). This correlation raises the possibility that glucocorticoids may be responsible for the initial expression of these properties in chromaffin cells. While levels of PNMT and PNMT catalytic activity are regulated by glucocorticoids in adult and embryonic chromaffin cells (Wurtman and Axelrod, 1966; Ciaranello et al., 1978; Bohn et al., 1981, 1982; Teitelman et al., 1982; Grothe et al., 1985; Siedl and Unsicker, 1989), it seems likely that the de novo expression of PNMT is not directly dependent on glucocorticoids. Experimental treatments that al- 
ter embryonic adrenal glucocorticoid levels in vivo and in vitro do not cause premature expression of PNMT or, conversely, delay or prevent its expression (Bohn et al., 1981, 1982; Teitelman et al., 1982; Anderson and Michelson, 1989: see, however Siedl and Unsicker, 1989). Glucocorticoids also appcar to influence enkephalin levels in adult chromaffin cells (Naranjo et al., 1986; La Gamma and Adler, 1987; Stachowiak et al., 1988). For example, hypophysectomy results in a decrease in enkephalin levels which can be partially reversed by administration of exogenous glucocorticoid (Stachowiak et al., 1988). The precise role of the pituitary-adrenocortical axis in the regulation of enkephalin, however, is unclear. Thus, although there is a temporal correlation between the rise in glucocorticoids and the appearance of L-Enk, it remains to be determined whether the presence or absence of glucocorticoids affects the timing and pattern of the initial expression of L-Enk.

Between E15 and E18, the proportion of chromaffin cells which contained NPY-IR increased significantly and was then maintained until birth. The majority of these cells were preferentially located in large clusters which exhibited intense NPYIR and less intense TH-IR compared with nonclustered cells. These clusters form initially in the medial portion of the gland, an area previously noted by Anderson and Axel (1986) to contain cells expressing SCG-10, a neuronal marker. It is not clear whether the increase is due to proliferation of NPY-IR cells within the clusters or recruitment of additional TH-IR precursor cells into the clusters.

The observation that the most intensely NPY-IR cells were located in clusters in which the density of cells was greater than in nonclustered cells raises the possibility that cell-cell contact plays a role in the regulation of NPY expression. Cell contact has been shown to affect neurotransmitter properties in cells of the sympathoadrenal lineage; it increases TH activity in PC-12 and bovine chromaffin cells (Lucas et al., 1979; Acheson and Thoenen, 1983) and induces choline acetyltransferase and substance $P$ in sympathetic neurons (Adler and Black, 1985, 1986; Kessler et al., 1986; Acheson and Rutishauser, 1988). By analogy, increased cell density, and hence greater cell contact in cell clusters, could enhance NPY expression; conversely, if the degree of cell contact were reduced, the level of NPY expression would decline. Of interest is the observation that the dense cell clusters present in embryonic adrenals elongate and decrease in packing density during early postnatal development; this correlates temporally with the decrease in the proportion of NPYIR cells. Increased cell-cell contact may influence not only the expression of NPY; it is possible that a number of properties of the clustered cells are altered by increased contact; that is, cell clustering may affect the entire phenotypic repertoire of these precursor cells which includes NPY, rather than being specific for NPY. This possibility is supported by the observations of Anderson and Axel (1986), who noted that the clustered cells in early adrenals expressed neuronal markers, while nonclustered cells did not, suggesting substantial phenotypic differences between the 2 subpopulations of chromaffin precursors. Further, although there is precedent for cell contact influencing the phenotype of crest-derived cells, it remains to be demonstrated whether the clustering is the cause or consequence of the differential expression of phenotypic markers.

Shortly after birth, the proportion of NPY-IR chromaffin cells decreases to adult values (approximately 40\%). The intenscly NPY-IR cell clusters were no longer evident, NPY-IR cells were evenly distributed throughout the adrenal gland, and the entire chromaffin cell population was uniformly TH-IR. The temporal correlation between the decrease in the proportion of NPY-IR cells and the disappearance of the dense cell clusters, coupled with the large proportion of cells present in large clusters during late cmbryonic development, raises the possibility that changes in this population of cells account for the postnatal decrease in the proportion of NPY-IR-producing cells. As discussed above, changes in cell-cell interactions that regulate NPY expression could be responsible. Additionally or alternatively, the intensely NPY-IR cells in the cell clusters could degenerate. Several lines of evidence (Anderson and Axel, 1986; Stemple et al., 1988; Henion and Landis, 1989) suggest that the clusters of intensely NPY-IR cells in the developing adrenal gland represent committed neuronal precursors. The clustered cells express several markers that are most commonly expressed by neurons, including the neuronal markers B2 and SCG-10 (Anderson and Axel, 1986), as well as intense immunoreactivity to antibodies against the surface molecules L1 and NCAM (Henion and Landis, 1989), and they lack the chromaffin marker, PNMT. Experiments in vitro have shown that when embryonic chromaffin cells are sorted for the B2-positive, presumably more neuronal population, significant numbers of cells survive only if grown in medium containing NGF, which supports the survival of sympathetic neurons (Anderson and Axel, 1986). Significantly, Anderson and Axel showed that the majority of these cells die in medium supplemented with the synthetic glucocorticoid dexamethasone. Based on these results, we predict that in vivo the glucocorticoid-rich and NGF-poor local environment of the adrenal gland is not sufficient to support the long-term survival of these cells. Given that the clusters contain a majority of the NPY-IR cells, degeneration of precursor cells in the clusters could account for the large decrease in the proportion of $\mathrm{TH}$ IR cells which express NPY. This hypothesis does not, however, explain the induction and regulation of NPY in the nonclustered population of chromaffin cells. Finally, disproportionate and robust cell division in nonclustered chromaffin cells, rather than selective loss of the clustered cell population, could account for our observations. However, preliminary studies in late embryonic and early postnatal animals with bromodeoxyuridine, which labels dividing cells, indicate that the rate of cell division is roughly equivalent in clustered and nonclustered populations; this argues against the selective expansion of the nonclustered subpopulation. If some or all of the clustered cells die, then it is likely that proliferative expansion of NPY-IR cells within the nonclustered subpopulation could generate the NPY-containing cells of the adult. The facts that NPY-IR nonclustered cells are only evident later than clustered NPY-IR cells and that they appear to increase in number with developmental age provide circumstantial evidence for the generation of a second NPY-IR subpopulation during late embryonic and early postnatal development which replaces the clustered NPY-IR population.

As in the case of NPY-IR, an increase in the proportion of TH-IR cells which were L-Enk-IR was observed; the proportion increased to approximately $40 \%$ between E16 and E20 and remained constant until birth. In contrast to NPY-IR, L-Enk was restricted to PNMT-IR cells, which were not included in the clusters. Shortly after birth, the proportion of L-Enk-IR cells decreased dramatically to adult values (10-15\%). It is possible that the arrival of preganglionic fibers and/or the onset of impulse activity represents an inhibitory influence on L-Enk expression and therefore restricts the number of chromaffin cells which express detectable levels of L-Enk. Surgical denervation 
of adult rat adrenal glands via splanchnic nerve transection results in a dramatic increase in the proportion of L-Enk-IR chromaffin cells (Schultzberg et al., 1978; Henion and Landis, unpublished observations). In addition, our preliminary results indicate that a much greater proportion of chromaffin cells expresses L-Enk-IR in dissociated, and therefore denervated, cell cultures of P10 adrenal glands than in situ. The postnatal appearance of preganglionic innervation is consistent with the postulated role of activity in decreasing the proportion of L-EnkIR cells. ChAT-IR nerve fibers were first detected on P2 and subsequently increased in number and intensity with further development, although we cannot be sure that the initial detectability of ChAT-IR fibers reflects the arrival of preganglionic fibers or the onset of impulse activity. Previous studies have described the presence of axons and occasional primitive synapses as early as E15 (Millar and Unsicker, 1981). At the light microscopic level, we have not observed any significant intermingling of NF 160-IR fibers with chromaffin precursors until after birth, suggesting that close apposition of preganglionic fibers with chromaffin cells does not occur prenatally. Consistent with this interpretation, little or no secretory response was observed in response to reflex stimulation evoked by insulin-induced hypoglycemia prior to one week of age (Lau et al., 1987). Together with the observations of the initial appearance of ChAT and L-Enk-IR in preganglionic fibers, it appears that functional innervation is not established prenatally. If the onset of preganglionic activity is responsible for the decreased number of L-Enk cells, given that 10-15\% of adult chromaffin cells produce immunocytochemically detectable levels of L-Enk, then the pattern of innervation or of activity of the preganglionic neurons would have to be unequal among the chromaffin cell population.

Adrenal chromaffin cells contain 2 different neuropeptides, NPY and L-Enk, which are not preferentially colocalized in the adult. Our results indicate that neuropeptide expression occurs early during the embryonic development of adrenal chromaffin cells and then undergoes first a striking increase and then a decrease in the proportion of cells that contain peptide. Previous studies provide evidence for the existence of distinct developmental mechanisms in the induction of the catecholamine synthetic enzymes, TH and PNMT. The asynchronous appearance and the topographical segregation of NPY and L-Enk expression in the developing adrenal gland suggest that both the induction and subsequent regulation of the neuropeptides NPY and L-Enk arc controlled independently. In addition, the survival of appropriate precursor cells and the possible death of inappropriate ones may have profound implications for the formation of the chromaffin cell population during development. Thus, a variety of regulatory mechanisms play a role in determining the mature transmitter phenotypes of even the relatively simple adrenal chromaffin cell system.

\section{References}

Acheson AL, Rutishauser U (1988) Neural cell adhesion molecule regulates cell contact-mediated changes in choline acetyltransferase activity of embryonic chick sympathetic neurons. J Cell Biol 106: $479-486$.

Acheson AL, Thoenen $\mathrm{H}$ (1983) Cell contact-mediated regulation of tyrosine hydroxylase synthesis in cultured bovine adrenal chromaffin cells. J Cell Biol 97:925-928.

Adler JE, Black IB (1985) Sympathetic neuron density differentially regulates transmitter phenotypic expression. Proc Natl Acad Sci USA 82:4296-4300.

Adler JE, Black IB (1986) Membrane contact regulates transmitter phenotypic expression. Dev Brain Res 30:237-241.
Aloe L, Levi-Montalcini R (1980) Comparative studies on the effects elicited by pre- and postnatal injections of anti-NGF, guanethidine and 6-hydroxydopamine in chromaffin cells and ganglion cells of the adrenal medulla and carotid body cells in infant rats. Adv Biochem Psychopharmacol 25:221-226.

Anderson DJ, Axel R (1986) A bipotential neuroendocrine precursor whose choice of cell fate is determined by NGF and glucocorticoids. Cell 47:1079-1090.

Anderson DJ, Michelson A (1989) Role of glucocorticoids in the chromaffin-neuron developmental decision. Int J Dev Neurosci 7:475487.

Bohn MC, Goldstein M, Black IB (1981) Role of glucocorticoids in expression of the adrenergic phenotype in rat embryonic adrenal gland. Dev Biol 82:1-10

Bohn MC, Goldstein M, Black IB (1982) Expression of phenylethanolamine $N$-methyltransferase in rat sympathetic ganglia and extra-adrenal chromaffin tissue. Dev Biol 89:299-308.

Bohn MC, Kessler JA, Golightly L, Black IB (1983) Appearance of enkephalin-immunoreactivity in rat adrenal medulla following treatment with nicotinic antagonists or reserpine. Cell Tissue Res 231: $469-479$.

Christie GA (1962) Developmental stages in somite and post-somite rat embryos, based on external appearance, and including some fcatures of the macroscopic development of the oral cavity. J Morphol 114:263-286.

Ciaranello RD, Wong DL, Berenbeim DM (1978) Regulation of phenylethanolamine-N-methyltransferase synthesis and degradation. II. Control of the thermal stability of the enzyme by an endogeneous stabilizing factor. Mol Pharmacol 14:490-501.

Cochard P, Goldstein M, Black IB (1979) Initial development of the noradrenergic phenotype in automatic neuroblasts of the rat embryo in vivo. Dev Biol 71:100-114.

Cohen AM (1972) Factors directing the expression of sympathetic nerve traits in cells of neural crest origin. J Exp Zool 97:167-182.

Coons, AH (1958) Fluorescence antibody methods. In: General cytochemical methods (Danielli JF, ed), pp 339-422. New York: Academic.

Coupland RE (1965) Electron microscopic observations on the structure of the rat adrenal medulla. J Anat 99:231-254.

Coupland RE (1972) The chromattin system. In: Handbook of experimental pharmacology Vol 33, Catecholamines (Balschko H, Muscholl E, eds), pp 16-45. Berlin: Springer.

DeChamplain J, Malmfors T, Olson L, Sachs Ch (1970) Ontogenesis of peripheral adrenergic neurons in the rat: pre- and postnatal observations. Acta Physiol Scand 80:276-288.

de Quidt ME, Emson PC (1986) Neuropeptide $Y$ in the adrenal gland: characterization, distribution and drug effects. Neuroscience 19:10111022.

Doupe AJ, Landis SC, Patterson PH (1985) Environmental influences in the development of neural crest derivatives: glucocorticoids, growth factors, and chromaffin cell plasticity. J Neurosci 5:2119-2142.

Eranko O (1955) Distribution of adrenaline and noradrenaline in the adrenal medulla. Nature 175:88-89.

Fontaine-Perus J, Chanconie M, LeDourain NM (1982) Differentiation of peptidergic neurones in quail-chick chimaeric embryos. Cell Diff 11:183-193.

Garcia-Arraras JE, Chanconie M, Fontaine-Perus J (1984) In vivo and in vitro development of somatostatin-like-immunoreactivity in the peripheral nervous system of quail embryos. J Neurosci 4:15491558.

Garcia-Arraras JE, Chanconie C, Ziller C, Fauquet M (1987) In vivo and in vitro expression of vasoactive intestinal polypeptide-like immunoreactivity by neural crest derivatives. Dev Brain Res 33:255265.

Grothe C, Hofmann H, Verhofstad A, Unsicker K (1985) Nerve growth factor and dexamethasone specify the catecholaminergic phenotype of cultured rat chromaffin cells: dependence upon developmental stage. Dev Brain Res 21:125-132.

Hayashi M, Edgar D, Thoenen H (1983) The development of substance $P$, somatostatin and vasoactive intestinal polypeptide in sympathetic and spinal sensory ganglia of the chick embryo. Neuroscience 10:31-39.

Henion PD, Landis SC (1989) Evidence for death of committed neuronal precursors in the developing adrenal gland. Soc Neurosci Abstr 15:884. 
Hillarp N-A, Hökfelt B (1953) Evidence of adrenaline and noradrenaline in separate adrenal medullary cells. Acta Physiol Scand 30:5568.

Howard MJ, Bronner-Fraser M (1985) The influence of neural tubederived factors on the differentiation of neural crest cells in vitro. I. Histochemical study on the appearance of adrenergic cells. I Neurosci 5:3302-3309.

Howard MJ, Bronner-Fraser M (1986) Neural tube-derived factors influence differentiation of neural crest cells in vitro: effects on activity of neurotransmitter biosynthetic enzymes. Dev Biol 117:45-54.

Joh TH, Geghman C, Reis D (1973) Immunochemical demonstration of increased accumulation of tyrosine hydroxylase protein in sympathetic ganglia and adrenal medulla elicited by reserpine. Proc Natl Acad Sci USA 70:2767-2771.

Johnson CD, Epstein ML (1986) Monoclonal antibodies and polyvalent antiserum to chicken choline acetyltransferase. J Neurochem 46:968-976.

Kessler JA, Conn G, Hatcher VB (1986) Isolated plasma membranes regulate neurotransmitter expression and facilitate effects of a soluble brain cholinergic factor. Proc Natl Acad Sci USA 83:3528-3532.

La Gamma EF, Adler JE (1987) Glucocorticoids regulate adrenal opiate peptides. Mol Brain Res 2:125-130.

Lau C, Ross LL, Whitmore WL, Slotkin TA (1987) Regulation of adrenal chromaffin cell development by the central monoaminergic system: differential control of norepinephrine and epinephrine levels and secretory responses. Neuroscience 22:1067-1075.

LeDouarin N, Teillet M (1974) Experimental analysis of the migration of neuroblasts of the autonomic nervous system and of neuroectodermal derivatives using a biological cell marking technique. Dev Biol 41:162-184.

Livett BG, Day R, Elde RP, Howe PRC (1982) Co-storage of enkephalins and adrenaline in the bovine adrenal medulla. Neuroscience 7: $1323-1332$

I ucas CA, Edgar D, Thoenen H (1979) Regulation of tyrosine hydroxylase and choline acetyltransferase activities by cell density in the PC12 rat pheochromocytoma clonal cell line. Exp Cell Res 121: $79-86$.

Lundberg JM, Terenius L, Hökfelt T, Martling CR, Tatemoto K, Mutt V, Polak J, Bloom S, Goldstein M (1982) Neuropeptide Y (NPY)like immunoreactivity in peripheral noradrenergic neurons and effects of NPY on sympathetic function. Acta Physiol Scand 116:477-480.

Max SR, Rohrer H, Otten U, Thoenen H (1978) Nerve growth factormediated induction of tyrosine hydroxylase in rat superior cervical ganglia in vitro. J Biol Chem 253:8013-8015.

Maxwell GD, Sietz PD, Chenard PH (1984) Development of somatostatin-like immunoreactivity in embryonic sympathetic ganglia. $\mathrm{J}$ Neurosci 4:576-584.

Millar TJ, Unsicker K (1981) Catecholamine-storing cells in the adrenal medulla of the pre- and postnatal rat. Cell Tissue Res 217:155170.

Mueller RA, Thoenen H, Axelrod J (1969a) Increase in tyrosine hydroxylase activity after reserpine treatment. J Pharmacol Exp Ther 169:74-79.

Mueller RA, Thoenen H, Axelrod J (1969b) Inhibition of transsynaptically increased tyrosine hydroxylase activity by cycloheximide and actinomycin D. Mol Pharmacol 5:463-469.

Naranjo JR, Mocchetti I, Schwartz JP, Costa E (1986) Permissive effect of dexamethasone on the increase of proenkephalin mRNA induced by depolarization of chromaffin cells. Proc Natl Acad Sci USA 83:1513-1517.

New HV, Mudge AW (1986) Distribution and ontogeny of SP, CGRP, SOM, and VIP in chick sensory and sympathetic ganglia. Dev Biol 116:337-346.

Norr S (1973) In vitro analysis of sympathetic neuron differentiation from chick neural crest cells. Dev Biol 34:16-38.

Otten U, Schwab M, Gagnon C, Thoenen H (1977) Selective induction of tyrosine hydroxylase and dopamine B-hydroxylase by nerve growth factor: comparison between adrenal medulla and sympathetic ganglia of adult and newborn rats. Brain Res 133:291-303.
Pelto-Huikko M, Salminen T, Hervonen A (1982) Enkephalin-like immunoreactivity is restricted to the adrenaline cells in the hamster adrenal medulla. Histochemistry 73:493-497.

Rohrer H, Acheson AL, Thibault J, Thoenen H (1986) Developmental potential of quail dorsal root ganglion cells analyzed in vitro and in vivo. J Neurosci 6:2616-2624.

Rothman RP, Specht LA, Gershon MD, Joh TH, Teitelman G, Pickel VM, Reis DJ (1980) Catecholamine biosynthetic enzymes are expressed in replicating cells of the peripheral but not the central nervous system. Proc Natl Acad Sci USA 77:6221-6225.

Schalling M, Seroogy K, Hökfelt T, Siew Yeen Chai, Hallman H, Persson H, Larhammar D, Ericsson A, Terenius L, Graffi J, Massoulie J, Goldstein M (1988) Neuropeptide tyrosine in the rat adrenal gland: immunohistochemical and in situ hybridization studies. Neuroscience 24:337-349.

Schultzberg M, Lundberg JM, Hökfelt T, Terenius L, Brandt J, Elde RP, Goldstein M (1978) Enkephalin-like immunoreactivity in gland cells and nerve terminals of the adrenal medulla. Neuroscience 3: $1169-1186$

Schultzherg M, Hökfelt T, Terenius L, Elfvin L-G, Jundberg JM, Brandt J, Elde RP, Goldstein M (1979) Enkephalin immunoreactive nerve fibers and cell bodies in sympathetic ganglia of the guinea-pig and rat. Neuroscience 4:249-270.

Seidl K, Unsicker K (1989) The determination of adrenal medullary cell fate during embryogenesis. Dev Biol 136:481-490.

Stachowiak MK, Lee PHK, Rigual RJ, Viveros OH, Hong JS (1988) Roles of the pituitary-adrenocortical axis in control of the native and cryptic enkephalin levels and proenkephalin mRNA in the sympathoadrenal system of the rat. Mol Brain Res 3:263-274.

Stemple DL, Mahanthappa NK, Anderson DJ (1988) Basic FGF induces neuronal differentiation, cell division, and NGF dependence in chromaffin cells: a sequence of events in sympathetic development. Neuron 1:517-525.

Teillet MA, Cochard P, LeDourain NM (1978) Relative roles of the mesenchymal tissues and of the complex neural tube-notochord on the expression of adrenergic metabolism in neural crest cells. Zoon $6: 115-122$

Teitelman G, Baker H, Joh TH, Reis DJ (1979) Appearance of catecholamine-synthesizing enzymes during development of the rat sympathetic nervous system: possible role of tissue environment. Proc Natl Acad Sci USA 76:509-513.

Teitelman G, Joh TH, Park D, Brodsky M, New M, Reis DJ (1982) Expression of the adrenergic phenotype in cultured fetal adrenal medullary cells: role of intrinsic and extrinsic factors. Dev Biol 89:450459.

Thibault J, Vidal D, Gros F (1981) In vitro translation of mRNA from rat pheochromocytoma tumors, characterization of tyrosine hydroxylase. Biochem Biophys Res Commun 99:960-968.

Thoenen H, Angeletti PU, Levi-Montalcini R, Kettler R (1971) Selective induction of tyrosine hydroxylase and dopamine B-hydroxylase in rat superior cervical ganglion by nerve growth factor. Proc Natl Acad Sci USA 68:1598-1602.

Tramu G, Pillez A, Leonardelli J (1978) An efficient method of antibody elution for the successive or simultaneous localization of two antigens by immunocytochemistry. J Histochem Cytochem 26:322324.

Verhofstad AAJ, Hökfelt T, Goldstein M, Steinbusch HWM, Joosten HWJ (1979) Appearance of tyrosine hydroxylase, aromatic aminoacid decarboxylase, dopamine B-hydroxylase and phenylethanolamine $\mathrm{N}$-methyltransferase during the ontogenesis of the adrenal medulla. Cell Tissue Res 200:1-13.

Wurtman RJ, Axelrod J (1966) Control of enzymatic synthesis of adrenaline in the adrenal medulla by adrenal cortical steroids. J Biol Chem 241:2301-2305.

Zigmond RE (1985) Biochemical consequences of synaptic stimulation: the regulation of tyrosine hydroxylase activity by multiple transmitters. Trends Neurosci 8:63-69. 